David G. Tompkins

\title{
Of Lightning Strikes and Bombs: The Tito-Stalin Split and its Effects on Polish and East German Society
}

The Tito-Stalin split came as a shock to East German and Polish communists and their fellow citizens. After being fêted as a friend postwar, in 1948 Yugoslavia was excluded from the socialist community at the outset of its consolidation, and thus carried freighted symbolic importance for Central Europeans. This article focuses on the attempts by the Socialist Unity Party (Sozialistische Einheitspartei Deutschlands, SED) and the Polish United Workers Party (Polska Zjednoczona Partia Robotnicza, PZPR) to create and then transform the image of Yugoslavia for pedagogical purposes during the postwar decade. It argues that party officials and their allies viewed a representation of Yugoslavia as both an opportunity and a threat, and shows that the sudden emergence of Feindbild Yugoslavia had significant effects on the worldviews of Poles and East Germans in the early Cold War.

Such images of friends and enemies played a key role in the worldview constructed by East German and Polish communists. Party leaders and their allies deployed these images, based in reality but cast to serve political goals, to help define and elaborate their preferred vision of society and to claim legitimacy for their ideological program. They shaped these profiles of the "other" and exhorted citizens to emulate or reject them accordingly. These images circulated throughout everyday life through popular media and proved essential to the parties' attempts to influence their populations. For citizens, these ubiquitous representations framed their lived experience of communism in Central Europe and also offered opportunities for negotiation and even resistance.

This paper looks at both the German Democratic Republic (GDR) and Poland as examples of the relationship of two bloc countries to Yugoslavia as well as its related representation there; examining both countries gives a sense of the range of possibility within the bloc and offers comparative insights. And Yugoslavia offers a compelling 
and unusual case, as its representation changed from that of friend to enemy (and then back again after 1953). It thus presented a challenge to the usual Manichean worldview that asserted the unstoppable forward march of communism over its capitalist and imperialist foes. The many characteristics of the image of Yugoslavia had been applied intensively if inconsistently in the postwar years, and could be put together in a myriad of ways to create an image useful to party leaders as well to an ordinary citizen. As simultaneously a real actor and a familiar symbol in the early Cold War, Yugoslavia was an important touchstone for Central European debates about Stalinism and the thaw.

\section{Yugoslavia as Heroic Friend, 1945-1948}

During the first postwar years, both East German and Polish communists found in Yugoslavia a key ally for the building of socialism and an important mobilizing tool with respect to their populations. An initial image of socialist Yugoslavia as a heroic example coalesced and spread in both countries before the abrupt about-face in the summer of 1948. This positive representation became more widespread in Poland, but proved important for many East German communists as well. For the Germans, the relationship was more fraught given the legacy of the war, while Poles celebrated an analogous resistance to Nazism. The Poles could also draw upon a notion of Slavic brotherhood, while their East German counterparts had to deal with anti-Slav sentiments. ${ }^{1}$

Prominent East German communists had a number of personal connections to the Yugoslav leadership, in that some had fought together in the Spanish Civil War. Walter Ulbricht had even helped Tito to travel from Moscow to Yugoslavia during the Second World War to fight. ${ }^{2}$ In the immediate postwar years, the Communist Party of Yugoslavia was a model for East German communists, following closely behind only the Soviet party in the eyes of many SED members. ${ }^{3}$ The uncertainty surrounding the fate of eastern Germany as well as the negative legacy of German involvement in the Balkans during the Second World War did, however, make contacts between the two parties and peoples more fraught.

The wartime legacy was, however, also usefully instrumentalized by the SED as it looked to the presence of tens of thousands of German prisoners of war in Yugoslavia. Thousands chose to help Yugoslavia rebuild after 1945, in a program that also included communist-inspired education. ${ }^{4}$ There was even a journal, Der Aufbau-für Arbeitsinitiative und Einsatz der deutschen und österreichischen Kriegsgefangenen in Jugoslawien

1 Selinić, Ambasada jugostowiańska, pp. 107-108; Behrends, Stalins slavischer Volkskrieg, pp. 79-108; Wippermann, Antislavismus, pp. 512-524.

2 Bock, Die Beziehungen zur SFRJ, pp. 233-251.

3 Weber, Die SED und der Titoismus.

4 Mählert, Die Partei hat immer recht!, p. 388. 
(Construction: For Work Initiative and Service of the German and Austrian Prisoners of War in Yugoslavia), for these Germans and interested individuals in Central Europe. ${ }^{5}$ A not-untypical article lauded the "united workers... as an example and model from which we can learn the most important and great things.... We have learned that only a united people that stays together and in which the working person is the most important citizen can realize the tremendous task of societal renewal." ${ }^{6}$ This and other articles explicitly evoked Yugoslav efforts towards unity and development as an ideal for Germans to follow. Similar reports with such framing also appeared in the press more broadly, as one in which former prisoners thanked the Yugoslavs and asserted: "We return to our homeland as new people. We take the spirit of progressive democracy and true popular government as a precious asset to implement in our new, developing Germany."' There was also a move to spread knowledge more widely back in eastern Germany through a German-Yugoslav Friendship Society, but these efforts were cut short by the split in $1948 .^{8}$ A Yugoslav delegation from the youth organization did visit the second Free German Youth (Freie deutsche Jugend, FDJ) meeting in 1947, the first international youth organization to do so. ${ }^{9}$ As late as the end of May 1948, plans to send two delegations, of journalists and cultural figures, to Yugoslavia were continuing apace. ${ }^{10}$

The press proved an essential forum in both countries for propagating an image of Yugoslavia, and both the country and its leader featured in extensive and positive coverage in the immediate postwar years, with over 100 articles annually in the main party-linked newspaper Neues Deutschland. Yugoslavia was depicted as fighting for peace and democracy, achieving the basis for socialism while engineering impressive economic growth and necessary agricultural reform. ${ }^{11}$ Other articles reported significant improvement in comparison to the supposedly benighted prewar period, especially with respect to educating society, with great progress made in education. ${ }^{12}$ Tito was portrayed as a strong leader, and his views were expressed in glowing terms through numerous articles. ${ }^{13}$

Gtos Ludu, the equivalent Polish newspaper, provided a similar image of Yugoslavia, also through hundred of articles from 1945 to 1948 . Tito was also portrayed here as a

5 Baer, Zwischen Anlehnung und Abgrenzung, pp. 226-35.

6 "Aus eigener Kraft" in Der Aufbau, Nr. 22 (May 1948), in Bundesarchiv (BArch), DY-34, 21399.

7 “Kriegsgefangenen danken Marschall Tito," Neues Deutschland (ND), 30 January 1947, p. 1; “Was Heimkehrer aus Jugoslawien berichten," ND,15 May 1948, p. 4.

8 "Auszug aus dem Protokoll N. 81 (II) der Sitzung des Zentralsekretariats vom 1. Juni 1948," p. 16, and "Betr. Gründung einer deutsch-jugoslawischen Gesellschaft," 23 May 1948, p. 17, in SAPMO-BArch, DY-30, IV 2/20/126.

9 Leonhard, Die Revolution entläßt ihre Kinder, p. 409.

10 Protokoll 78 der Sitzung des Sekretariats, 26 May 1948, SAPMO-BArch, DY-30, IV 2/2.1/201, pp. 3-4.

11 "Wirtschaftswunder Jugoslawien," ND, December 5, 1947, p. 4; $N D$, "Bodenreform in Jugoslawien," 23 January 1947, p. 1.

12 Volksbildung im neuen Jugoslawien," ND, 9 September 1947, p. 1.

13 See for example "Jugoslawien vor den Wahlen: Tito zu Innen- und außenpolitischen Fragen," ND, 10 November 1946, and "Jugoslawiens Außenpolitik: Klare Sprache des Marschalls Tito," ND, 9 August 1947. 
heroic and wise leader of both Yugoslavia and the Balkans, a crucial friend of the emerging people's democracies, and as a fighter against fascism and for socialism. ${ }^{14}$ Reports focused on Yugoslavia's successes and celebrated the close relationship between the two countries. ${ }^{15}$ In a related example, a featured article in the weekly magazine Kuźnica positively described Yugoslav political and cultural life as refracted through the monthlong visit of leading literary figure Adam Ważyk in the fall of $1947 .{ }^{16}$ A handful of Yugoslav writers made appearances in Polish magazines at this time, and roughly a dozen books were translated into Polish. ${ }^{17}$

These links between Yugoslavia and Poland were more extensive than in the case of eastern Germany, due to the presence of a Polish state that could more easily organize such connections as well as a shared wartime legacy of resistance and a notional Slavic brotherhood. ${ }^{18}$ These exchanges started at the very top and extended widely in the immediate postwar years. Tito visited Warsaw in March 1946, and the two countries signed agreements on friendship and mutual help, as well as on cultural exchange. ${ }^{19} \mathrm{Pol}-$ ish president Bolesław Bierut returned the visit during that same fall. Close relations and numerous exchanges also existed between the militaries of the two countries. ${ }^{20}$ They also exchanged youth work brigades of roughly 100 young men and women in the summers of 1946 and 1947 to help with postwar reconstruction. The Yugoslav delegation in 1946 particularly impressed their hosts as an example to Polish youth with their laudable qualities in work, culture, and education. ${ }^{21}$

The Poles and Yugoslavs organized an impressive number of initiatives, especially given the postwar difficulties. Cultural officials in the Polish Ministry of Culture worked to realize an ambitious plan of exchanges that included films, radio broadcasts, concerts, exhibitions, and students, artists, and cultural officials. ${ }^{22}$ One high-profile effort was the exhibition "The Art of the Nations of Yugoslavia in the $19^{\text {th }}$ and $20^{\text {th }}$ Centuries" appearing in the National Museum of Warsaw and then in Krakow in the spring of 1948, with nearly 40,000 visitors in the capital and around 10,000 in Krakow. ${ }^{23}$

14 Zaćmiński, Josip Broz Tito, pp. 283-285.

15 Zaćmiński, Od przyjaźni do wrogości, pp. 212-219.

16 Małczak, Croatica, pp. 126-128. See also the many articles in AAN, TPPJ, 22.

17 Selinić, From love and cooperation, p. 240.

18 Behrends, Die 'sowjetische Rus', pp. 95-114; Biegański, Polsko-jugostowiańskie relacje, pp. 282-283.

19 Tito toured Warsaw and visited a number of industrial sites. (http://www.repozytorium.fn.org.pl/?q=pl/ node/4149, accessed 14 July 2018.) See also Dimitrijević, Tito jako gośc, pp. 172-193.

20 Dimitrijević, The Yugoslav Polish military-technological relations, pp. 189-190.

21 "Sprawozdanie z pobytu Jugosłowianskiej Młodzieżowej Brygady Pracy w Polsce, 17.VII-2.IX.46, in AAN, TPPJ, 2, p. 14. See also Pavlović, Razmena omladinskib brigada poljske, p. 211.

22 See the Protokoły warszawskiej podkomisji polsko-jugosławskiej dla spraw realizacji konwencji o współpracy kulturalnej from 1947 in AAN, MKiS, BWKzZ, 132. For a description of this period using Yugoslav sources, see Selinić, From love and cooperation, pp. 237-248; using Polish sources, see Biegański, Polsko-jugostowiańskie relacje, pp. 275-295.

23 “Realizacja Planu Pracy, 1-12.47-1.12.48," AAN, MKIS, BWKzZ, 132; Małczak, Croatica, p. 734. 
Another significant institution for creating and propagating a positive, pedagogical image of Yugoslavia was the Society for Polish-Yugoslav Friendship (Towarzystwo Przyjaźni Polsko-Jugosłowiańskiej), an organization with 60,000 members across the country. ${ }^{24}$ It had an ambitious program to help realize its efforts to create mass awareness of Yugoslav achievements. ${ }^{25}$ The Society facilitated a wide range of exchanges going both directions, and tried to leverage events such as Tito's 1946 visit to spread knowledge of Yugoslavia among the Polish population..$^{26}$ Another important moment was Yugoslav "Republic Day" on November 29, when the Society sought to organize major events and press coverage around Yugoslavia. For the 1947 iteration, it developed talks for schools and other educational institutions to popularize the "new Yugoslavia" among young people. ${ }^{27}$ More general lectures in Warsaw on the Yugoslav struggle for national liberation were "relatively well attended," in the opinion of the Yugoslavs, seemingly indicating a certain level of interest from the capital's population. ${ }^{28}$

Even though an awareness of socialist Yugoslavia was not particularly well entrenched in either country during the chaotic postwar years, a useful image had been established. The anti-fascist Yugoslavs had liberated themselves and were building socialism under their dynamic leader, and this image could be evoked to inspire and educate East Germans and Poles.

\section{Tito's Yugoslavia as Hated Enemy, 1948-1954}

This all of course changed dramatically in the summer of 1948-the "Yugoslav bomb," in the recollection of Polish writer Jerzy Putrament, or the "lightning strike," as conceptualized by young German communist (and later historian) Hermann Weber. ${ }^{29}$ Conflicts over alternate paths to socialism and Soviet hegemony within the communist world intensified early that year, climaxing in the expulsion of Yugoslavia from the Cominform by the other member parties, including the PZPR, at the end of June $1948 .{ }^{30}$ Although the SED was not a member, it joined in the condemnation and proclaimed its allegiance to the USSR and its particular variant of socialism. ${ }^{31}$ In the context of the deepening Cold War and related Stalinist paranoia, and despite the links

24 See article from Kurier Codzienny, 26 February 1948, AAN, TPPJ, 22.

25 See the protocols in AAN, TPPJ, 1.

26 See the protocols in AAN, TPPJ, 7.

27 Protokoł, 20 November 1947, ibid., p. 183.

28 Selinić, From love and cooperation, p. 239.

29 Putrament, Pót wieku: Zagranica, p. 327; Weber, Damals als ich Wunderlich hiess, p. 189.

30 For some of the main literature see: Kramer, Stalin, the Split with Yugoslavia, pp. 29-63; Perović, The Tito-Stalin Split, pp. 32-63; Gibianskii, The Soviet-Yugoslav Split, pp. 17-36; Rajak, From Regional Role, pp. 65-86; Banac, With Stalin against Tito.

31 Norman Naimark notes that Soviet advisers pushed the SED to discuss and publicize the Cominform resolutions more fully. (Naimark, The Russians in Germany, p. 315.) 
described above, key hardliners in the East German and Polish communist leadership embraced the emerging negative image of Yugoslavia as a useful tool to educate their populations about the correct Stalinist path. At this crucial turn towards consolidation of the Soviet bloc, Yugoslavia became one of the symbols used to purge those who encouraged different political outcomes, including a that particular national roads to communism would not be tolerated. Yugoslavia was portrayed as a dangerous example of the betrayal of correct communist ideals, hypernationalism, and the seduction of the West, and proved a useful pegagogical example against which "proper" socialist society could be constituted during this early peak of the Cold War. The favorable image established and propagated during the immediate postwar years did not just disappear, however, and indeed was evoked by those who desired an alternative to Stalinism.

For the SED in the years following June 1948, Yugoslavia functioned as a negative foil for proponents of the Stalinist path to construct an East German identity. From the popular press to specialized party literature, East German media launched a fullthroated propaganda campaign over the next months and years. The very first communiqué in the press set out these terms clearly: Yugoslavia had made major mistakes and East Germans must learn from them by emulating the Soviet Union and building the "party of the new type" on the Soviet model. ${ }^{32}$ Henceforth, Neues Deutschland, like the press across eastern Germany, regularly condemned Tito and Yugoslavia. Tito featured in the title of dozens of articles each year for the following years, and was mentioned in hundreds of articles total. Many of these referred to the "Tito-Clique" and "TitoDictatorship," and portrayed the Yugoslav leader in aggressive terms as in league with Western imperialists and reactionaries. He was accused of deploying fascist methods and having betrayed his communist ideals for money. The Yugoslav population was consistently shown as suffering under his rule, which offered an telling example to those East Germans who might push for a similar path. ${ }^{33}$

In addition to newspapers, the campaign used a wide variety of other outlets. In a long article in Einheit, the party theoretical journal, in the fall of 1948, Rudolf Herrnstadt laid out the case against Yugoslav “ideological corruption” in strong language. ${ }^{34}$ Several pamphlets that year explained the nature of the split and its implications for East Germans to party members as well as a wider audience. One of the main brochures intended for wider consumption, Lessons from the Degeneration of the Yugoslav Party Leadership, carried its pedagogical intent right in the title. In handy, user-friendly

32 “Erklärung des Zentralsekretariats der SED zur jugoslawischen Frage,"ND, 4 July 1948, p. 2; “Arbeiterartei auf Abwegen," Berliner Zeitung, 4 July 1948, p. 2.

33 See for example the articles: "Offener Verrat der Tito-Clique," ND, 8 July 1949; "Die Tito-Clique—eine Agentur der Weltreaktion,” ND, 20 November 1949; “Jugoslawien in der Gewalt der Tito-Faschisten,” ND, 14 February 1950; "Das erbärmliche Schicksal Tito-Jugoslawiens," ND, 24 August 1951).

34 Rudolf Herrnstadt, "Einige Lehren aus den Fehlern der KPJ” in Einheit 3/9 (September 1948), pp. 788-802, here p. 788. 
format, it featured the Cominform Resolution and the SED's official resolution, with explanatory contributions by German, Soviet, and other bloc communists. Wilhelm Pieck, co-chairman of the SED and future president of the GDR, provided the introduction, which encouraged Germans to learn from the mistakes exhibited by the Yugoslavs, in particular the need to follow the Soviet path to communism and to build a "party of a new type." ${ }^{5}$ A similar pamphlet from party leader Walter Ulbricht was directed more narrowly to SED members, whom he exhorted to study and learn from the Yugoslav mistakes, and to overcome their own errors. ${ }^{36}$ Party officials organized meetings in workplaces to discuss Yugoslavia, and facilitators were provided materials as a guide. The themes of a "political education evening" in November 1948 centered around Yugoslavia's mistakes, in particular "self-glorifying nationalist policies" and a failure to emulate the Soviet Union, and the lessons that Germans should draw. ${ }^{37}$ In summer 1949, the Volkspolizei (People's Police) were targeted with extensive materials about Yugoslavia's egregious mistakes and encouraged to learn from this for their own fight for socialism alongside the Soviet Union. ${ }^{38}$ Translations of Renaud de Jouvenel's Tito: Marshal of Traitors and Dino Kjosseff's Tito without Masks, intended for a broad audience and printed in the tens of thousands, sought to spread this negative image of Yugoslavia throughout society. ${ }^{39}$

Also to this end, and on the cultural front, Austrian communist Ernst Fischer's play Der große Verrat (The Great Betrayal), a hardline condemnation of Tito that presented a starkly bi-polar world with only one good side, appeared all across the GDR in 195051. ${ }^{40}$ It received its premiere at the German Theater in Berlin in summer 1950 to long applause from an audience that included Walter Ulbricht and President Wilhelm Pieck, and enthusiastic reviews that praised it as a great "political-pedagogical" success. ${ }^{41}$ This production was used for even more explicitly propaganda purposes, as it was staged to great acclaim at the Verwaltungsakademie Walter Ulbricht on the eve of the $33^{\text {rd }}$ anniversary of the October Revolution. ${ }^{42}$ It also appeared in Leipzig and Dresden, and furthermore served to inaugurate the new theater in Magdeburg on the eve of Stalin's birthday. ${ }^{43}$

35 Die Lehren aus der Entartung.

36 Ulbricht, Die Bedeutung der Entschliessung.

37 “Über die Entartung der Führung der KPJ," Sozialistische Bildungshefte 3/11 (Berlin: Dietz Verlag, 1948).

38 "Wohin der Nationalismus der Tito-Clique in Jugoslawien führt,"Informationsmaterial der Volkspolizei, Nr. 4 (Berlin: Verlag für Polizei-Fachliteratur, July 1949).

39 Each had an initial print run of 20,000. de Jouvenel, Tito: Marschall der Verräter and Kjosseff, Tito obne Maske; Baer, Zwischen Anlehnung und Abgrenzung, pp. 79-81.

40 “Der große Verrat von Ernst Fischer. Programmheft Städtische Theater Leipzig," Schauspielhaus 1951 (Leipzig: Leipzig Selbstverlag, 1951).

41 “Zeittheater großen Stils," Neue Zeit, 20 July 1950, p. 2; see also Hans Ulrich Erlau, "Premiere, Diskussion und Kritik", Neue Zeit, 21 July 1950. The premiere was also linked to a discussion with Fischer in Juli 1950 in Kulturbundhaus with various cultural luminaries. (Neue Zeit, 19 July 1950, p. 4.)

42 “Sie müssen ein neuer Mensch werden!" Neue Zeit, 14. November 1950, p. 3.

43 "Premiere, Diskussion, und Kritik," Neue Zeit, 21 July 1950, p. 4. 
The show trials of László Rajk in Hungary in 1949 and Rudolf Slánský in Czechoslovakia in 1952 focused on Tito as a major enemy and thus provided regular focus on Yugoslavia. ${ }^{44}$ Articles continued to appear regularly in the East German press in the fall of 1949 that attacked Tito for his treacherous acts towards Hungary and the communist movement. ${ }^{45}$ The party journal Einheit featured a number of articles on the Rajk trial, and depicted Tito as a fascist traitor and Yugoslavia as a tool of imperialists. ${ }^{46}$ Such reporting became even more intense with the Slánský trial, as the SED issued a major resolution in spring 1953 and gave it widespread publicity through the press, pamphlets, and discussions at all levels of the SED. It portrayed Yugoslavia as a deepening threat to socialism as it used terror to establish dominance over the working class as part of an imperialist project. ${ }^{47}$ The party leadership believed all this would "arm the party and the German working class with political vigilance and determination... to secure ideological, political, and organizational unity." ${ }^{48}$ In Poland, an article in the aftermath of the Slánský trial portrayed Yugoslavia as the first example of treasonous behavior that threated socialism, and portrayed Tito at the heart of the crimes exposed in the show trials across the region. It warned against following a Titoist example that would inevitably lead to fascist dictatorship and capitalist misery. ${ }^{49}$

Poland's main party newspaper represented Yugoslavia in similar fashion through hundreds of articles, with an increase of negative intensity from summer 1948 through 1949. Most offered a portrayal similar to that seen in the GDR, with regular use of "klika Tito," “Tito dictatorship," and "Tito terrorist regime," as well as choice epithets to describe Tito as a fascist, renegade, traitor, and as the "favorite of the reactionary riffraff." Articles were generally careful to place blame on Tito for the damaging effects of his policies on the population, and also to describe in highly favorable terms those Yugoslav communists who were opposing him..$^{50}$ In showing the negative qualities and actions of Tito and his associates, these frequent press reports offered a pedagogical representation of how East Germans and Poles should behave.

Outside of the daily press, many other Polish publications worked to spread this negative image of Yugoslavia under Tito. Prominent journalist Stanisław Brodzki penned a blistering attack on Tito in 1950, in a large print run of 25,000, with chapter titles like

44 For more on the pedagogical aspects of the show trials, see Feinberg, Curtain of Lies, Ch. 1.

45 "Tito jahrelangen Verrats überführt," Berliner Zeitung, 13 September 1949, p. 1; "Terror und Mord im Auftrage Titos," Berliner Zeitung 21 September 1949, p. 1.

46 Einheit 5/1 (1950).

47 "Über die Durchführung." See also the two-page reprint of Matern's speech with the same title in ND, 19 May 1953, pp. 3-4.

48 SAPMO-BArch, NY 4076, Direktive des Sekretariats des ZK zur Behandlung des Beschlusses des ZK "Einige Lehren aus dem Prozess gegen das Verschwoererzentrum Slansky" in allen Parteiorganisationen, 9 January 1953.

49 Witold Larski, "Po procesie praskim" in Sprawy międzynarodowe 1/21 (1953), pp. 20-33.

50 Zaćmiński, Od przyjaźni do wrogości and Josip Broz Tito w propagandzie. 
"Five Years of Chauvinist Megalomania," "The Trojan Horse of Imperialism," and "Fascist Terror." ${ }^{51}$ The de Jouvenel title mentioned above as well as Jacque Duclos' Yugoslavia under the Terror of the Tito Clique also appeared in Poland for public consumption, as did home-grown works like Rajk, Tito, Wallstreet. Prozes w Budapeszcie, which had a high print run of 30,000. ${ }^{52}$ As the last title suggests, as in East Germany Tito and Yugoslavia were folded into the show trials of László Rajk in Hungary and then Rudolf Slánský, and remained prominent Feindbilder in both countries throughout the Stalinist era.

Polish officials also sought to saturate the public space with this negative image using whatever means available. Authorities organized around two dozen anti-Tito Yugoslavs who stayed in Poland after the split, and mobilized them to engage in publicity, often at Polish Radio, against Tito. ${ }^{53}$ The group put out a bulletin, For Victory, wrote articles for the Polish press, and spoke at meetings designed to condemn Tito and his associates. A student group was founded in Gdańsk and had members across Poland. In the fall of 1949, banners were hung outside the Yugoslav embassy that condemned "Titoist provocateurs and instigators." ${ }^{4}$ A high profile trial of Yugoslav official Milić Petrović that same year received considerable press attention that framed his case as illustrative of the Yugoslav threat to Polish socialism. He was convicted of spying and received a further four years for the distribution of illegal publications. ${ }^{55} \mathrm{~A}$ book with a 10,000 copy print run was published in the aftermath, painted a dark picture of $\mathrm{Yu}-$ goslav perfidity, and made it clear the lessons to be drawn: "The Polish nation, like all nations that love freedom and peace, sees today... the shameful path of the traitorous Tito clique and the true role of the Anglo-American imperialists. The Polish working class, with the entirety of our healthy and patriotic-thinking society, repeatedly have condemned this betrayal with indignation...In addition to their spying, Titoist agents and provocateurs are trying to spread the poison of nationalist-trotskyist propaganda throughout Polish society and organize political diversion against the foundations of our democratic Polish state." 56

The Yugoslavs did not simply accept to this flood of negative publicity, but sought to offer their own counter-image through the spreading of materials in the two countries.

51 Brodzki, Titowszczyzna.

52 De Jouvenel and Rolland, Tito, marszatek zdrajców; Duclos and Rolland, Jugostawia pod terrorem kliki Tito; Cywiak and Jurys, Rajk, Tito, Wallstreet.

53 See "Krótka informacja o grupie komunistów jugosłowianskich-emigrantów politycznych w Polsce" in AAN, KC PZPR, 237/XXII/456, pp. 13-16. They were offered Polish citizenship in 1956. (AAN, KC PZPR, 237/ XXII/863, Notatka informacyjna dot. towarszyszy jugosłowiańskich przebywających w Polsce, October 3, 1956, p. 13.) Those who went back suffered hard labor or arrest. (Instytut Pamięci Narodowej [AIPN], BU 01419/54/D, tom. 1, no date, 1961, Notatka informacyjna, signed W. Olender, p. 108.).

54 See the various documents in AAN, KC PZPR, 237/XXII/465. See also Wołobujew, Jugostowiańscy emigranci politiczni, pp. 195-203; Banac, With Stalin against Tito, pp. 221-231; Gulic, Jugostowiańska emigracja, pp. 154168; Pavlović, Propaganda Kominformu, pp. 60-78.

55 Szwandrok, Stosunki Polsko-Jugostowianskie, pp. 60-61.

56 Proces Milica Petrovica, pp. 30, 32. 
In Poland in 1949 alone, the Yugoslav embassy distributed nearly 23,000 informational bulletins, over 22,000 newspapers, and more than 4000 brochures. ${ }^{57}$ The latter, with titles like "About the False and Unjust Accusations against the Communist Party of Yugoslavia" and "The Real Reasons for the Slanders Directed against Yugoslavia," were addressed to individuals, party offices, and factory meeting rooms. The Yugoslav embassy also offered Polish-language radio broadcasts. ${ }^{58}$ Polish officials took this counterpropaganda seriously as a destabilizing threat and sought to block its distribution.

In East Germany, materials in support of Yugoslavia also came in, from West Berlin and elsewhere, and were a source of instability. ${ }^{59}$ Indeed, the initial SED declaration in early July 1948 condemned the Yugoslavs for distributing materials in Berlin. ${ }^{60} \mathrm{In}$ the fall of 1949, there were numerous reports of pro-Yugoslav materials appearing in Berlin. ${ }^{61}$ On the fifth anniversary of the Cominform Resolution in the summer of 1953, the Stasi described a 20-page pamphlet sent through the mail to the "socialists of the GDR" that contained "shameless agitation against the Soviet Union... and sought to glorify Tito and his policies as well as to laud the situation in Yugoslavia as model socialism." ${ }^{62}$ Coming on the heels of the June 17 Uprising, when hundreds of thousands of East Germans took to the streets in protest of the SED's variant of socialism, such activity seemed threatening indeed.

Some East Germans and Poles were not willing to accept the official, negative post1948 image, either because they supported some version of the Yugoslav socialist vision, or because they hoped the dispute signaled the end of the communist era in their country. In the immediate aftermath of the publication of the June 28 Cominform Resolution, students in Krakow reacted "with hope and joy" and celebrated Tito for breaking with Stalin. ${ }^{63}$ Over the following months, Polish security officials noted repeated praise for Yugoslavia's split with the USSR. ${ }^{64}$ Yugoslavia as a symbol of protest was frequently evoked by workers at times of unrest and dissatisfaction; some even threatened "a revolution like in Yugoslavia" if their wages were reduced. ${ }^{65}$ In the following years, leaflets and graffiti appeared in workplaces with slogans like "Long Live Tito!" and similar proYugoslav phrases. ${ }^{66}$

57 AAN, KC PZPR, 237/XXII/456, "Notatka informacyjna dot. wrogiej działalności uprawianej przez titowców wobec Polski,” p. 46; AAN, KC PZPR, 237/VII/116, Meldunki z terenu Nr. 32, 5 March 1949, p. 214.

58 See the reports in AAN, KC PZPR, 237/VII/2695, pp. 47-58, and IPN, BU 1572/1513; Selinić, Ambasada Jugostowiañska, pp. 112-114.

59 Klein, "Für die Einheit, "pp. 118-120.

60 "Erklärung des Zentralsekretariats der SED zur jugoslawischen Frage,"ND, 4 July 1948, p. 2.

61 See materials in SAPMO-BArch, DY-30, IV 2/4/384.

62 Information Nr. 1008, BStU, MfS, AS 9/57, Bd. 3a, B1. 373-387 (Hauptbericht, 1. Expl.); also AS 9/57, Bd. 3b, B1. 1-53 (Anlagen, alle: 1. Expl.), 8 July 1953. www.ddr-im-blick.de, accessed 6 April 2016.

63 IPN, BU 1572/1513, Raport specjalny (no date, but early July 1948), p. 27.

64 AAN, KC PZPR, 237/VII/119, Meldunki z terenu nr. 203, October 10, 1949, p. 34; Jarosz and Pasztor, Wkrzywym zwierciadle, p. 131.

65 AAN, KC PZPR, 237/VII/118, Załącznik do Meldunków nr. 184, 16 September 1949, p. 398.

66 See the reports from spring 1951 in AAN, KC PZPR, 237/VII/3830, pp. 123-34, 201. 
Significant support of Tito's Yugoslavia also continued in East Germany, to the great worry of SED hardliners. The aforementioned German prisoners of war sympathetic to both communism and Yugoslavia came under significant party mistrust and often only unwillingly suppressed the latter part of their biography after $1948 .{ }^{67}$ The SED Control Commission undertook a thorough review of former Yugoslav POWs in the fall of 1949 and discovered a worrying level of support for Tito. ${ }^{68}$ Two state officials, in the Interior Ministry and the Ministry of Industry, headed up "groups" that were sympathetic to Tito. ${ }^{69}$ In Thüringen, yet another former POW had reportedly extended his pro-Tito influence over 50 of the 60 men in his working group. Even in the summer of 1950, he continued to receive the main trade union journal from Yugoslavia and publicly praised Tito's version of socialism. ${ }^{70}$ More generally, contacts between the national trade unions of the two countries perhaps surprisingly continued into 1949 with letters expressing interest in the exchange of ideas and experiences. ${ }^{71}$ Other, smaller-scale acts of rebellion were linked to support for Tito, such as throwing rocks through windows during party meetings. ${ }^{72}$

The highest profile threat to the new image of Yugoslavia and, relatedly, to the hardline vision of communism coming into being in eastern Germany, centered on Wolfgang Leonhard. He was an SED member who had lived in the Soviet Union from 1935 to 1945 , and was one of the members of the Ulbricht Group that secretly returned to Germany from Moscow in April 1945. He occupied a particularly influential position as an instructor at the main party school, "Karl Marx," where he had significant contact with young cadres. One of them, the aforementioned Hermann Weber, recalls a 1947 speech that "painted a positive image with ardent zeal" and asserted that Tito "was one of the greatest leaders of the communist world movement." ${ }^{73}$ Leonhard was very sympathetic to the Yugoslav position in summer 1948, and shared his opinions, as well as Yugoslav materials, with colleagues and students at the school and beyond, to considerable sympathy and interest. ${ }^{74}$ His support for Yugoslavia—and critique of the SED's course-met with interest and sympathy from a significant number of his students and colleagues. ${ }^{75}$ In March 1949, he fled to Yugoslavia, where he gave several

67 Kühnrich and Hitze, Deutsche bei Titos Partisanen, pp. 250-51; Mählert, Die Partei, p. 388; SAPMO-BArch, DY-30, 42021, Protokoll Nr. 51 der Sitzung des Politbüros am 18.10.49, p. 6.

68 SAPMO-BArch, DY-30, 71315, Protokoll, Sitzung der ZPKK mit den Kommissionsmilgiedern der LPKK, 9 March 1950, pp. 120-152.

69 Ibid., p. 131.

70 SAPMO-BArch, DY-30, IV 2/4/384, SED Hausmitteilung, 4 July 1950, p. 7.

71 See letters from early March 1949 in SAPMO-BArch, DY-34, 5660.

72 SAPMO-BArch, DY-30, 71315, "Protokoll der Sitzung der ZPKK mit den Vorsitzenden der Landes-ParteiKontrollkomm am 21.10.49," p. 15.

73 Weber, Damals als ich Wunderlich hiess, p. 94.

74 Leonhard, Im Fadenkreuz der SED, pp. 289-90; Ibid., Meine Geschichte der DDR, pp. 99-118.

75 Ibid., Die Revolution, pp. 447-459, 467-479. 
radio broadcasts in the following months that were heard over Radio Belgrade by some GDR citizens. ${ }^{76}$ Leonhard also penned two short pro-Yugoslav books, for distribution back in East Germany, that sought to counter official SED claims and offer a positive counter-image. ${ }^{77}$ The SED leadership took this situation very seriously, and attempted to suppress these works. The party's central control commission conducted a massive investigation of Leonhard's influence at the party school and in related organizations like the FDJ, in hopes of minimizing any effects, and also organized numerous public meetings and self-critical statements. ${ }^{78}$ The director of the Saxon police school, for example, was removed for his support of Leonhard. ${ }^{79}$ Weber recalls "an unleashed wave of meetings and shocked declarations, and hours-long discussions about faulty vigilance." 80

\section{Conclusion}

The new, negative representation of Yugoslavia was mobilized seamlessly into the larger contexts of building the new Stalinized parties and purging opposition to the SED and PZPR. ${ }^{81}$ In the dominant narrative taking shape in both countries, Yugoslavia became useful shorthand for deluded communists who had been subverted by the West, and representative of a dangerous path to be avoided. Tito and his country became cautionary examples of arrogance, hypernationalism, the betrayal of correct communist ideals, the corruption of capitalism, and the seduction of the West, and proved a useful pegagogical example against which the "proper" socialist society could be defined during this initial peak of the Cold War. But the highly positive image propagated during the immediate postwar years did not just disappear, and indeed was mobilized by those who wished for an alternative to the Stalinist system. The confusion and tensions around the revised representation of Yugoslavia produced a significant dissonance among party members and the population-while a consistent worldview that implied the success of communism was undermined, these ideological fissures provided opportunities to explore alternate ideas and to question the correctness of party doctrine. The interaction with and representation of Yugoslavia was thus an important site for contesting what communism would actually look like in East Germany and Poland. For party leaders who desired to construct their vision, for reformers who wanted to modify that vision, and for ordinary citizens who sought to have their voices heard, Yugoslavia was a crucial touchstone in the early Cold War and the decades following.

76 Leonhard, Im Fadenkreuz der SED, p. 306.

77 Leonhard, Die Wabrheit über das sozialistische Jugoslawien, and ibid., Kominform und Jugoslawien.

78 See the huge file in SAPMO-BArch DY-30, IV 2/4/398. See also Weber, Die SED und der Titoismus, pp. 246254.

79 DY-30, 71315, "Protokoll der Sitzung der ZPKK mit den Vorsitzenden der LPKK und deren Stellvertretern am 8.6.49,"p. 8 .

80 Weber, Damals, p. 309.

81 Klein, Für die Einheit und Reinheit, pp. 116-124. 


\title{
Sources and literature
}

\section{Archival sources}

Archiwum Akt Nowych (AAN)

Komitet Centralny, Polska Zjednocznona Partia Robotnicza (KC PZPR)

Ministerstwo Kultury i Sztuki (MKiS), Biuro Współpracy Kulturalnej z Zagranicą (BWKzZ)

Towarzystwo Przyjaźni Polsko-Jugosławiańskiej (TPPJ)

Archiwum Instytutu Pamięci Narodowej (AIPN)

Behörde des Bundesbeauftragten für die Stasi-Unterlagen (BStU), Ministerium für Staatssicherheit (MfS)

Stiftung-Archiv der Parteien und Massenorganisationen im Bundesarchiv (SAPMO-BArch)

\section{Newspapers and journals}

\author{
Der Aufbau \\ Berliner Zeitung \\ Einheit \\ Informationsmaterial der Volkspolizei \\ Kurier Codzienny \\ Neue Zeit \\ Neues Deutschland (ND) \\ Sozialistische Bildungshefte \\ Sprawy międzynarodowe

\section{Printed primary sources}

Brodzki, Stanisław, Titowszczyzna. Szturmowy oddziat imperializmu. Warsaw: Książka i Wiedza, 1950.

Cywiak, Józef and Roman Jurys, Rajk, Tito, Wallstreet. Prozes w Budapeszcie. Warsaw: Książka i Wiedza, 1949.

de Jouvenel, Renaud, Tito: Marschall der Verräter. Berlin: Dietz, 1952.

de Jouvenel, Renaud and Albert Rolland, Tito, marszatek zdrajców. Warsaw: Książka i Wiedza, 1951.

Die Lehren aus der Entartung der Jugoslawischen Parteiführung. Berlin: Dietz, 1948.

Duclos, Jacques and Albert Rolland, Jugostawia pod terrorem kliki Tito. Warsaw: Wydawnictwo "Prasa Wojskowa", 1950.

Kjosseff, Dino G., Tito ohne Maske. Berlin: Dietz, 1953.

Leonhard, Wolfgang, Die Wahrheit über das sozialistische Jugoslawien: Eine Antwort auf die Kominform-Verleumdungen. Belgrade: Jugoslovenska knjiga, 1949.

Leonhard, Wolfgang, Kominform und Jugoslawien. Über einige grundsätzliche Fragen des Kominform Konflikts. Belgrade, 1949.

Proces Milica Petrovica: czyli kulisy "Dyplomacjï" Titowskiej w Polsce. Warsaw: Książka i Wiedza, 1950.

Putrament, Jerzy, Pót wieku: Zagranica. Warsaw: Czytelnik, 1969.

Über die Durchführung des Beschlusses des ZK der SED "Lehren aus dem Prozess gegen das Verschwörerzentrum Slansky”. Berlin: Dietz, 1953. 


\section{Literature}

Baer, Friederike, Zwischen Anlehnung und Abgrenzung: Die Jugoslawienpolitik der DDR 1946 bis 1968. Köln: Böhlau, 2009.

Behrends, Jan, Die ‘sowjetische Rus' und ihre Brüder. Die slawische Idee in Russlands langem 20. Jahrhundert. Osteuropa 59, no. 12 (2009), pp. 95-114.

Behrends, Jan, Stalins slavischer Volkskrieg: Mobilisierung und Propaganda zwischen Weltkrieg und Kaltem Krieg (1941-1949). Agnieszka Gąsior, Lars Karl, and Stefan Troebst (eds.), Post-Panslavismus: Slavizität, Slavische Idee und Antislavismus im 20. und 21. Jahrbundert. Göttingen: Wallstein, 2014, pp. 79-108.

Biegański, Zdzisław, Polsko-jugosłowiańskie relacj kulturalne w latach 1945-1948. Momčilo Pavlović, Nebojša Stambolija and Andrzej Zaćmiński (eds.), Polska i Jugostawia po II wojnie śrwiatowej. Bydgoszcz: Wydawnictwo Uniwersytetu Kazimierza Wielkiego, 2016, pp. 275-295.

Bock, Siegfried, Die Beziehungen zur SFRJ. Siegfried Bock et al. (eds.), DDR-Aussenpolitik im Rückspiegel: Diplomaten im Gespräch. Münster: Lit Verlag, 2004, pp. 233-251.

Dimitrijević, Bojan B., The Yugoslav Polish military-technological relations 1918-1991. Momčilo Pavlović and Andrzej Zaćmiński (eds.), Polska i Jugostawia w stosunkach międzynarodowych po II wojnie światowej. Bydgoszcz: Wydawnictwo Kazimierza Wielkiego, 2014, pp. 189-190.

Dimitrijević, Bojan. Tito jako gość i gospodarz. Wizyty marszałka Tity w Polsce I polskich przyoódców w Jugosławii (1946-1978). Momčilo Pavlović, Nebojša Stambolija, Paweł Wawrzyszuk and Andrzej Zaćmiński (eds.), Polska i Jugostawia w XX wieku. Polityka, spoteczeństwo, kultura. Bydgoszcz: Wydawnictwo Uniwersytetu Kazimierza Wielkiego, 2018, pp. 172-193.

Feinberg, Melissa, Curtain of Lies: The Battle over Truth in Stalinist Eastern Europe. New York: Oxford University Press, 2017.

Gulić, Milan, Jugosłowiańska emigracja kominformowska w Polsce. Momčilo Pavlović, Nebojša Stambolija and Andrzej Zaćmiński (eds.), Polska i Jugostawia po II wojnie światowej. Bydgoszcz: Wydawnictwo Uniwersytetu Kazimierza Wielkiego, 2016, pp. 154-168.

Jarosz, Dariusz and Maria Pasztor, W krzywym zwierciadle: polityka wtadz komunistycznych w Polsce w świetle plotek i pogtosek z lat 1949-1956. Warsaw: Wydawnictwo Fakt, 1995.

Klein, Thomas, "Für die Einheit und Reinheit der Partei." Die innerparteilichen Kontrollorgane der SED in der Ära Ulbricht. Köln: Böhlau, 2002.

Kühnrich, Heinz and Franz-Karl Hitze, Deutsche bei Titos Partisanen 1941 - 1945: Kriegsschicksale auf dem Balkan in Augenzeugenberichten und Dokumenten. Schkeuditz: GNN Verlag für Sachsen/Berlin, 1997.

Leonhard, Wolfgang, Die Revolution entläßt ibre Kinder. Cologne: Kipenheuer \& Witsch, 1981.

Leonhard, Wolfgang, Im Fadenkreuz der SED. Vierteljahrshefte für Zeitgeschichte 46/2 (1998), pp. 289-90.

Leonhard, Wolfgang, Meine Geschichte der DDR. Berlin: Rowohlt, 2007.

Mählert, Ulrich. Die Partei hat immer recht! Parteisäuberungen als Kaderpolitik in der SED (1948-1953). Hermann Weber (ed.), Terror: stalinistische Parteisäuberungen, 1938-1953. Paderborn: Schöningh, 1998, pp. 351-457.

Małczak, Leszek, Croatica: literatura i kultura chorwacka w Polsce w latach 1944-1989. Katowice: Wydawnictwo Uniwersytetu Śląskiego, 2013. 
Naimark, Norman, The Russians in Germany: A History of the Soviet Zone of Occupation, 19451949. Cambridge, MA: Harvard University Press, 1995.

Pavlović, Momčilo, Razmena omladinskih brigada poljske i jugoslavije 1946-1947. godine. Momčilo Pavlović and Andrzej Zaćmiński (eds.), Polska i Jugostawia w stosunkach międzynarodowych po II wojnie swiatowej. Bydgoszcz: Wydawnictwo Kazimierza Wielkiego, 2014, pp. 203-212.

Pavlović, Momčilo, Propaganda Kominformu wobec władz jugosłowiańskich w latach 19481953. Przykład Polski. Momčilo Pavlović, Nebojša Stambolija, Paweł Wawrzyszuk and Andrzej Zaćmiński (eds.), Polska i Jugostawia w XX wieku. Polityka, spoteczeństwo, kultura. Bydgoszcz: Wydawnictwo Uniwersytetu Kazimierza Wielkiego, 2018, pp. 60-78.

Selinić, Slobodan, From love and cooperation to rejection and resentment: Yugoslav-Polish cultural cooperation 1945-1949. Momčilo Pavlović and Andrzej Zaćmiński, (eds.), Polska i Jugostawia w stosunkach międzynarodowych po II wojnie światowej. Bydgoszcz: Wydawnictwo Kazimierza Wielkiego, 2014, p. 240.

Selinić, Slobodan. Ambasada jugosłowiańska w Polsce (1945-1949). Momčilo Pavlović, Nebojša Stambolija and Andrzej Zaćmiński (eds.), Polska i Jugostawia po II wojnie światowej. Bydgoszcz: Wydawnictwo Uniwersytetu Kazimierza Wielkiego, 2016, pp. 105-116.

Szwandrok, Dariusz, Stosunki Polsko-Jugosłowianskie w latach 70. XX wieku. Ph.D. Diss, University of Rzeszów, 2015.

Ulbricht, Walter, Die Bedeutung der Entschliessung des Informbüros über die Lage in der KP Jugoslawiens und die Lehren für die SED. Berlin: Dietz, 1948.

Weber, Hermann, Damals als ich Wunderlich hiess: Vom Parteihochschüler zum kritischen Sozialisten. Berlin: Aufbau, 2002.

Weber, Hermann, Die SED und der Titoismus: Wolfgang Leonhard zum 90. Geburtstag. Deutschland-Archiv 44/2 (2011), (http://www.bpb.de/geschichte/zeitgeschichte/deutschlandarchiv/54018/sed-und-titoismus), accessed 5 April 2016.

Wippermann, Wolfgang, Antislavismus. Uwe Puschner, Walter Schmitz and Justus H. Ulbricht (eds.), Handbuch zur "Volkischen Bewegung,"1871-1918. München: Saur, 1999, pp. 512-524.

Wołobujew, Wadim, Jugosłowiańscy emigranci politiczni w powojennej Polsce. Jan Olaszek et al. (eds.), Yesterday: studia z historii najnowszej. Warsaw: IPN, 2017, pp. 195-203.

Zaćmiński, Andrzej, Josip Broz Tito w propagandzie centralnego dziennika prasowego PPR (Gtosu Ludu) i PZPR (Trybuny Ludu) w latach 1947-49. Aleksander Jankowski and Jacek Maciejewski (eds.), Interpretatio rerum gestarum. Studia ofiarowane Profesorowi Januszowi Ostoja-Zagorskiemu w 70. rocznice urodziń. Bydgoszcz: Wydawnictwo Uniwersytetu Kazimierza Wielkiego, 2013, pp. 275-296.

Zaćmiński, Andrzej, Od przyjaźni do wrogości-wizerunek Jugosławii w propagandzie Polskiej Partii Robotniczej/Polskiej Zjednoczonej Partii Robotniczej (1947-1949). Momčilo Pavlović and Andrzej Zaćmiński (eds.), Polska i Jugostawia w stosunkach międzynarodowych po II wojnie światowej. Bydgoszcz: Wydawnictwo Kazimierza Wielkiego, 2014, pp. 212-219. 


\section{Summary \\ David G. Tompkins \\ Of Lightning Strikes and Bombs: The Tito-Stalin Split and its Effects on Polish and East German Society}

This paper focuses on the attempts by the East German and Polish workers' parties to create a useful image of Yugoslavia for pedagogical purposes during the postwar decade. A positive representation took shape in the years before the split in both countries. Thereafter, confusion around the revised representation of Yugoslavia produced a significant dissonance among party members and the population. The positive image propagated during the immediate postwar years did not just disappear and indeed was mobilized by those who wished for an alternative to the Stalinist system. The interaction with and representation of Yugoslavia was an important site for contesting what communism would actually look like in East Germany and Poland. For party leaders who desired to construct their vision, for reformers who wanted to modify that vision, and for ordinary citizens who sought to have their voices heard, Yugoslavia was a crucial touchstone in the early Cold War. 